\title{
GENDER AND LANGUAGE MAINTENANCE USED AMONG THE BALINESE IN KARANG BAYAN
}

\author{
I Ketut Suardana ${ }^{1 *}$, Kamaluddin Yusra ${ }^{2}$, Atri Dewi Azis ${ }^{3}$ \\ University Of Mataram \\ *e-mail: ketutsuardana2404@gmail.com
}

\begin{abstract}
This study aimed to identify the dominant gender of role and the types of roles gender in maintain Balinese in Karang Bayan. This study used quantitative descriptive research to analyze data of maintaining Balinese. The numbers of data were three families of interaction analyzed as the data source. The result of data provided that the female is the most prominent Balinese used than the male. The females who speak the Balinese language reach $53.1 \%$ and the males have $8.8 \%$. The total of data presents the languages used which concerned with Balinese used. The percentage shown that the Balinese communities prefer speak Sasak language to the Balinese language. The Sasak language used by female was $53.1 \%$ and the male reached $73 \%$. The percentage of data indicated Balinese used occurred language shift in the communities Bali in Karang Bayan. Nevertheless, the result of the conversation in three families found the roles of gender refer to the branch of pragmatic used namely vocabulary, hypercorrection, hostility, intensifier, and filler. The most prominent roles are fillers used by the female. The main family use of the Balinese was dominant in pragmatic used by filler that the average was $80 \%$.
\end{abstract}

Keywords: Language maintenance, Pragmatic, Roles of gender, and Balinese Karang Bayan.

\section{INTRODUCTION}

Indonesia has many islands spreading from Sabang to Merauke. Indonesia has a wide variety of languages in which Indonesians use their languages differently. The native speakers used their language as identities where they are from. Hence, the vernaculars have an important role in a community to show the existence of the cultural society itself among the language diversities in Indonesia.

Sasak language is one of native language used by Lombok people. Lombok Island has about 2.7 million speakers of Sasak in 2010, roughly 85 percent of the Lombok population (Wikipedia, 2020). Various ethnics of tribe people live in Lombok for a long time ago. Many kinds of immigrant spread in Lombok, one of them is particularly the Balinese. According to the International Organization for Migration (IOM) (2018) a migrant is any person who is moving or has moved across an international border or within a state away from his/her habitual place of residence. Bailah (2019) said there are some reasons the immigrants to immigrate namely the demography, unavailable jobs, the population density, the status social and politic.

The population of Balinese is the second-highest reach $15 \%$ of the population of the Bali tribe (Wikipedia, 2021). Balinese ethnics groups currently circled by the majority of Sasak tribe which has influenced its habit such as the language used. As the majority, Sasak people dominate the environment and also language used in Karang Bayan. Hence, the male and female (Bali people) conduct their activities whereby the Bali language is utilized in the Sasak environment.

The usage of Bali language involves the man and women, they obtain the second language in the different ways. The male acquired their second language derived from outside instead of the female prefers to obtain their second language from at home because of the men more have received the job outside, and female prefers to stay in the home as the household. Based on Gender Social Norms in BBC (2020) reveals that nearly $55 \%$ men said they are more entitled to a job than women. Thus, 
Sasak language and Balinese might not be separated from the human beings, both of them are the important of the genders to communicate each other.

The Bali people of Karang Bayan communicate with Sasak people start from the youngest to the oldest. Intercommunication is always conducted between males and females for their activities to communicate with the Sasak people. Thus, there is a difference of genders occurs between the female and male by using Bali language to converse with Balinese itself. Women Balinese have the different role from male in which the role of women prefers to work at home. Additionally, the usage of the Bali language and the Sasak language are multilingualism in the communication of the daily activities that take place in Karang Bayan village. This study only focuses on the roles of gender in maintain Balinese used.

\section{RESEARCH METHOD}

\section{Research Design}

This study employed descriptive method. Creswell, (2009) research designs are the plans and the procedures for research to detailed methods of data collection and analysis. This study implied the participant observing and concerned with the ethnography study which is a particular human society. In the other words, descriptive method can obtain data through recording, observation and note taking.

\section{Sources of Data}

In obtaining the data of this study, the researcher conducted research at Karang Bayan, West Nusa Tenggara. The data of this study were primarily extracted from 5 families as the participants to obtain the data. The conversation of families consisted of the father, the mother, children, they analyzed as the data. Therefore, this study only classified the gender in maintain Balinese used. It is mean that the data were categorized within the usage of the roles of gender theory.

\section{Collecting Data}

In elaborating and presenting detail and comprehended description of refined language maintenance among members of noble Bali family at Karang Bayan village. this study needs to gather natural conversation, words, utterance produced by the speaker. Therefore, in order to obtain reliable data, I conducted these techniques namely observation, recording, and note taking.

\section{Analysis Data}

The data of Balinese spoken in Karang Bayan village was analyzed through the following steps:

\section{Identification}

In this level, I identified the participants (speech community) and the context of their interaction. In participant identification, it concerns on the ethnic background, social status, age, histories of migration of the area, and the interactions. It also identified the context of culture, situation, and domain.

\section{Description}

I described the language choice used by Bali community in different language usedand how often they use Bali language by scoring and in form of percentage.Additionally, this study provided the table of percentage to identify the total of dominant languages used by genders as the following; 
Table 1. scale of the tendency of roles in maintaining Balinese used according to the genders of respondent.

\begin{tabular}{|c|c|c|c|c|c|c|c|}
\hline \multirow[t]{3}{*}{ Participants } & \multirow[t]{3}{*}{ Quantity/ person } & \multicolumn{6}{|c|}{ Languages } \\
\hline & & \multicolumn{2}{|l|}{ Sasak } & Balinese & Bahasa & \multirow[t]{2}{*}{ Bali-sasak } & Bali-sasak-bahasa \\
\hline & & $f$ & $\%$ & $f \quad \%$ & $f \quad \%$ & & $\%$ \\
\hline Total & & & & & & & \\
\hline Female & 12 & 985 & 53.1 & 26.8 & 9.3 & 2.9 & 7.3 \\
\hline Male & 12 & 1074 & 72 & 8.8 & 6.6 & 7.3 & 4.3 \\
\hline
\end{tabular}

\section{Explanation}

The last step is explanation. I explained the use of Balinese in the domains of family and how strong they maintain it based on the result of the previous data analysis. It showed what kinds of role gender is dominantly used. And, explaining what is percentage mostly done.

\section{FINDINGS AND DISCUSSIONS}

Research Finding

The data found out the percentage of maintaining Balinese language used by the genders as following.

Table 1.1. scale of the tendency of roles in maintaining the Balinese used according to the genders of respondent.

\begin{tabular}{|c|c|c|c|c|c|c|c|c|c|c|c|c|}
\hline \multirow[t]{3}{*}{ Participants } & \multirow[t]{3}{*}{ Quantity/person } & \multicolumn{11}{|c|}{ Languages } \\
\hline & & \multicolumn{2}{|c|}{ Sasak } & \multicolumn{2}{|l|}{ Bali } & \multicolumn{3}{|c|}{ Bahasa } & \multicolumn{2}{|c|}{ Bali-Sasak } & \multicolumn{2}{|c|}{$\begin{array}{l}\text { Bali-Sasak- } \\
\text { Bahasa }\end{array}$} \\
\hline & & $f$ & $\%$ & f & $\%$ & f & $\%$ & & $f$ & $\%$ & $f$ & $\%$ \\
\hline & Group I & & & & & & & & & & & \\
\hline Female & 5 & 443 & 39.7 & 570 & $51^{*}$ & 74 & 6 & 6 & 14 & 1.25 & 15 & 1.3 \\
\hline \multirow{2}{*}{ Male } & 5 & 535 & 82 & 25 & 3.8 & 73 & & 1.1 & 10 & 1.5 & 9 & 1.3 \\
\hline & Groups II & & & & & & & & & & & \\
\hline Female & 4 & 303 & 58 & 81 & & $7 *$ & 71 & 13.8 & 22 & 4,3 & 37 & 7.1 \\
\hline \multirow[t]{2}{*}{ Male } & 4 & 311 & 70 & 41 & 9 & & 28 & 6.3 & 46 & 10.4 & 17 & 3.8 \\
\hline & Groups III & & & & & & & & & & & \\
\hline Female & 3 & 239 & 61.7 & 53 & & & 29 & 7.5 & 13 & 3.3 & 53 & 13.7 \\
\hline Male & 3 & 228 & 66 & 47 & & & 9 & 2.6 & 35 & 10.1 & 27 & 7.8 \\
\hline \multirow[t]{2}{*}{ Total } & 12 & 985 & 53.1 & & & $8^{*}$ & & 9.3 & & 2.9 & & 7.3 \\
\hline & 12 & 1074 & 72 & & 8 & & & 6.6 & & 7.3 & & 4.3 \\
\hline
\end{tabular}

Based on the table above is provided that the first family has 10 Bali people which divided two genders within 5 Bali of females and 5 Bali of males. Therefore, the total of participants are 24 Bali people who divided into two genders which are 12 females and 12 males. All of data increase each of genders. The usage of languages referred to the result of data that have derived from three families above. Nevertheless, the total of languages used based on two genders who are the most prominently Sasak language used by males is 1074 words which reach on $72 \%$ than the Balinese used is only on $8.8 \%$ used.

\section{Pragmatic roles of Balinese maintenance in the Karang Bayan communities}

In this section, the data is concerned with the pragmatic roles of Balinese maintenance. The study used the theory of Pearson (cited in Hanifa, 2014) related to roles of genders which is the branch of pragmatic in language used. The findings of pragmatic roles might be calculated into the table below: 
LISDAYA: jurnal linguistik (terapan), sastra, dan budaya

URL. http://lisdaya.unram.ac.id/index.php/lisdaya

\begin{tabular}{lccccc}
\hline Pragmatics Roles & \multicolumn{5}{c}{ Languages } \\
\cline { 2 - 6 } & & Balinese & Sasak & Bahasa \\
\hline Hostility & $f$ & $\%$ & $f$ & $\%$ & $f$ \\
\hline Fillers & 3 & $9.3 \%$ & 29 & $90.6 \%$ & \\
\hline Vocabulary & 5 & $16 \%$ & 25 & $80 \%$ & \\
\hline Hypercorrection & & & 12 & $100 \%$ & \\
\hline Intensifiers & & & 19 & $100 \%$ & \\
\hline
\end{tabular}

Based on the table found several kinds of roles pragmatics used which are hostility, fillers, vocabulary, hypercorrection, and Intensifiers. The usage of filler is the most dominant used by Sasak language. The Sasak language presented 25 time by using the filler, it might be average on $80 \%$. The total of pragmatic roles used might be seen that Sasak language raised four pragmatics roles namely hostility, fillers, vocabulary, hypercorrection, and intensifiers.

\section{Discussion}

The result of data might indicate that Balinese used by genders in KarangBayang communities is language shift of Balinese used in Karang Bayan. The communities do not speak Balinese, but the Sasak language used is the mostly used Bali people in their environment. The cases of this study have the same phenomena with the study of Muhammad Isnaeni. Both studies deal with the maintain of language used as minority. However, this study has the different of data in which the study of Muhammad Isnaeni (2021) indicated the usage of Bajo language was always used. Bajo people speak Bajo language with their communities, although Bajo people are minority tribe which reside in east Lombok. Furthermore, the data of study investigated Balinese is language shift occurred in Karang Bayan. It means that Balinese people preferred speak Sasak language to their first language. The Balinese people live around the mostly of Sasak tribe involved Balinese is shifted.

Nevertheless, the data found out from the role pragmatic of Balinese maintenance used by genders that the most dominant used is the filler roles. The conversation occurred between females and males that the most dominant filler role is the males. The filler role might be used when people respond the statement of intercalators. The usage of filler relates to answer the conversation in order to not sticking on. The verbal fillers and vocal fluencies frequently occur in people's communication with others.

\section{CONCLUSION Conclusion}

The result of study provided the percentage of dominant language used by the genders. The female and male have the different of Balinese used which are the females speak Balinese are $26.6 \%$ and the males reach $8.8 \%$. Both percentages have the minimum of Balinese used. Balinese people prefer Sasak language used to their language. The data stated the genders who the females speak Sasak language reach $53.1 \%$ and male speak Sasak language reach $72 \%$. The result of data might be indicated the Balinese people do not speak their first language, but they speak Sasak language as their activity. Therefore, the study concluded that the female speakers play dominant roles in maintaining the use of the Balinese language is the community. In other words, the usage of Balinese is said language shift occurred on Bali communities in Karang Bayan.

Nevertheless, the result of conversation found the roles pragmatic used that refer several the roles of gender namely hostility, fillers, hypercorrection, intensifiers, and vocabulary. However, the most prominently roles of used by genders is fillers used. The males prefer use fillers to communicate to the females. Those are one of branch pragmatics roles played by 
the female speakers in conversations gender from expression of hostility, fillers, exercise of words use (vocabularies), correction of falls word use and intensifiers of pragmatic expression. However, the main family use of the Balinese was dominant in pragmatic hostility and filler. Both have the same average dominant pragmatics were hostility had $90.6 \%$ and fillers had $80 \%$.

\section{REFERENCES}

Bailah. (2019). Pengelolaan Administrasi Penduduk Desa. Ponorogo:Uwais Inspirasi Indonesia.

Creswell, Jhon.W. (2009). Research Design; Pendekatan Kuantitatif, Kualitatif, dan Mixed.Yogyakarta; Pustaka Pelajar.

Eckert, Penelope and Sally McGonnellGinet. (2003). Language and gender. Cambridge:Cambridge University Press.

Gender Social Norms. (2020). International Women's Day. Indonesia: BBC News.

International Organization for Migration (IOM). (2017). World Migration Report 2018.
Isnaeni,Muhammad. (2021). Bajo Language Maintenance Used at Maringkik Island East

Lombok. Thesis. Mataram: Mataram University.

Lakoff, Robin. (2004). Language and Women's Place. Oxford University press.

Pearson, Judy Comelia. (1985). Gender and communication. Lowa: Wm.C. Brown Siahaan.

Pascarina, Halifa (2014). A Sociolinguistic Analysis of Topics in Cross-Gender Interaction in one for the money Movie .Thesis.Yogyakarta: Universitas Yogyakarta.

Speer, Susan. (2005). Gender Talk: Feminism, Discourse, and conversation Analysis. New York: Routledge.

Wikipedia.org. (2020).Sasak Language on https://en.wikipedia.org/wiki/Sasak language.

Wikipedia.org. (2021). Pulau Lombok on https://en.wikipedia.org/wiki/Pulau Lombok. 